\title{
Icelandic Inland Wetlands: Characteristics and Extent of Draining
}

\author{
Olafur Arnalds ${ }^{1,2}$ • Jon Gudmundsson ${ }^{1}$ • Hlynur Oskarsson ${ }^{1}$ • \\ Sigmundur H. Brink ${ }^{1} \cdot$ Fanney O. Gisladottir ${ }^{1}$
}

Received: 27 October 2015 / Accepted: 1 June 2016 / Published online: 9 June 2016

(C) The Author(s) 2016. This article is published with open access at Springerlink.com

\begin{abstract}
Iceland has inland wetland areas with soils exhibiting both Andosol and Histosol properties which are uncommon elsewhere on Earth. They are generally fertile, with higher bird-nest densities than in similar wetlands in the neighboring countries, with nutrients released by rapid weathering of aeolian materials of basaltic nature. Icelandic inland wetlands cover about $9000 \mathrm{~km}^{2}$ constituting $19.4 \%$ of the vegetated surfaces of the island. The wetland soils are often 1-3 m thick and store 33 to $>100 \mathrm{~kg} \mathrm{C} \mathrm{m}^{-2}$. They have been subjected to broad-scale subsidy-driven draining for agricultural purposes. About $47 \%$ of Icelandic inland wetlands are impacted by drainage. The ditch network extends about $30,000 \mathrm{~km}$, mainly in lowland areas, where about $70 \%$ of the wetland areas are impacted. There are $>1$ million wetland patches, most of them $<1 \mathrm{ha}$. Much of the wetlands impacted from drainage are not used for intensive agriculture such as hay-making, however some are used for grazing. There is a need to prioritize the protection of undrained wetlands and their restoration based on a broad range of factors.
\end{abstract}

Keywords Wetlanddraining - Andosols · Wetland patch size · Gleyic

Olafur Arnalds

oa@lbhi.is

1 Agricultural University of Iceland, Árleyni 22, 112 Keldnaholt, Iceland

2 United Nations University Land Restoration Training Program, Árleyni 22, 112 Keldnaholt, Iceland

\section{Introduction}

High latitude wetlands with an elevated organic content make up a large proportion of Earth's wetlands (e.g., Mitsch and Gosselink 2007). Iceland, an island in the North-Atlantic Ocean, has diverse wetlands ranging from the coast to the interior highland, including marshes, estuaries, ponds, lakes and rivers. The wetlands addressed in this paper are the inland palustrine wetlands, mostly fens with both organic or inorganic soils (see definitions in Cowardin et al. 1979), which we here also term 'inland fen wetlands' or simply 'inland wetlands'. They were termed "mires" ("mýrar" in Icelandic) in an overview by Gardarsson (1998). Sloping fens are a common feature of the fiords and valleys formed during the last glaciation which cut into the Tertiary basalts whereas the greatest extent of topogenous fens are found within the gently sloping lowlands of west and south Iceland. Alluvial fens are located along some of the larger rivers, particularly in north and east Iceland. Palsa wetlands are found in isolated areas in the central highlands. Intertidal flats and inland marshes are not covered in this paper $\left(559 \mathrm{~km}^{2}\right.$ and $387 \mathrm{~km}^{2}$, respectively, numbers based on the CORINE cover for Iceland).

The Icelandic wetlands are strongly influenced by the volcanic nature of the island and by intense aeolian deposition ("volcanic loess"), which separate Icelandic wetlands from most other wetlands on the globe. The volcanic and aeolian (loess) influences make these inland wetlands fertile with a relatively high $\mathrm{pH}$ and favorable nutrient availability (Arnalds 2004, 2015 Ch 8; Oskarsson et al. 2004). The fertility is reflected by high breeding bird densities, which often are $>10$ times higher in Iceland than for the same species in the UK and $>2$ times that of The Netherlands (Johannesdottir et al. 2014; Gunnarsson et al. 2015). The inland fen wetlands are important habitat for many bird populations in Iceland (Gunnarsson et al. 2006) with some of them important 
internationally (Einarsson et al. 2002). There have been extensive studies on changes in species composition of plants following drainage impacts (Magnusson 1998). Thorhallsdottir et al. (1998) found that the occurrence of rare wetland plant species was higher in areas with limited drainage disturbance. The extensive draining of Icelandic wetlands (addressed below) has had significant influence on both the distribution and overall abundance of Icelandic birds (Thorleifsson 1998; Skarphedinsson and Thorleifsson 1998). The wetland draining, along with the introduction of the American mink (Mustela vison), are considered to be the main reasons for the local extinction of the water rail (Rallus aquaticus), Iceland's only rail species (Skarphedinsson and Thorleifsson 1998).

Icelandic inland fen wetlands were subjected to widespread drainage during the twentieth century for agricultural purposes, with a large proportion of the wetlands being disturbed. Drainage for various purposes is still a threat to the remaining undisturbed wetlands. The Agricultural University of Iceland has generated nationwide geographical databases for land cover, including wetlands, and has surveyed the extent and impact of wetland drainage. The estimate of the extent and impact of drainage has been carried out in relation to the Icelandic national reporting to the UN Framework Convention on Climate Change (Hellsing et al. 2016). The main goal of this paper is to provide a general overview of the soils of the inland wetlands in Iceland and present an estimate of their extent, disturbance by drainage and the patch size of the remaining undrained wetlands based on relatively high resolution data.

\section{Background and General Characteristics of the Wetlands}

Iceland, a $103,000 \mathrm{~km}^{2}$ volcanic island, is located just south of the Arctic Circle, between $63^{\circ}$ and $66^{\circ}$ north latitude, and $13^{\circ}$ to $24^{\circ}$ west longitude. The climate is relatively mild in spite of the high geographic latitude, the reason being the oceanic climate and the effect of the Gulf Stream that brings warm waters to the shores of Iceland. It is worth noting that continental areas at the same latitudes, in Siberia and Canada for example, experience much colder climates than Iceland, particularly in winter.

Iceland has about 30 active volcanic systems, fed by a volcanic mantle plume under the island (hotspot), with eruptions occurring every 3-5 years (Thordarson and Höskuldsson 2008). The oldest rocks are from the late Tertiary, but much of the surface is covered by rocks $<3$ million years old, with widespread Holocene lava and tephra deposits. Glaciers cover about $11 \%$ of the country and many active volcanoes are located under ice. The volcanism provides the parent materials of Icelandic soils through tephra deposition and aeolian redistribution of volcanic materials, resulting in the formation of Andosols. The volcanic materials are primarily poorly crystalline basalt grains with rapid weathering rates, which results in the formation of allophane, ferrihydrite and imogolite (Arnalds 2015 Ch. 9). Areas outside the active volcanic regions are primarily made up of Tertiary basalt piles, but the Quaternary glaciation has cut deep valleys into the Tertiary rock formation. The porosity of the Tertiary rocks has been partially plugged by secondary minerals such as calcite, silica minerals, zeolites and clays by chemical weathering (e.g. Ehlmann et al. 2012), resulting in slow hydraulic conductivity and higher water tables with more frequent occurrence of wetlands within the Tertiary Formation than in the active volcanic regions (Arnalds and Oskarsson 2009).

For centuries, the fen wetlands were used for grazing by livestock and harvested for hay. The wetland sward also provided sod for house construction (Sigurdardottir 2007). Intermittently flooded wetlands were important sources of hay in many parts of the country and often shared within the community. The more organic soils provided peat for fuel (Thorsteinsson 1975).

Draining the wetlands primarily took place during the latter part of the twentieth century and was subsidized by the government. The draining was part of the effort to enhance agricultural production and "food safety" in the post-World-War II era, but also an effort to reduce the migration of people from rural sections to fast growing urban areas (see Helgadottir et al. 2013). The drainage efforts were sustained for almost 50 years in spite of substantial overproduction of meat and dairy products. Dairy and lamb meat production constitute the major proportion of Icelandic agriculture (data from Statistics Iceland February 2013; www.statice.is) and characterize the rural landscape (Fig. 1a). Currently there are about 26,000 dairy cows and 75,000 head of cattle in all, 460,000 winterfed sheep ( $>1.3$ million grazing sheep in summer) and about 80,000 horses. Sheep and cattle rearing is highly dependent on hay making in the summer as the cold winter means that animals are kept indoors in winter (see Helgadottir et al. 2013). Approximately half of the hayfields are on drained wetland soils (Wöll et al. 2014).

Previous estimations of the extent of wetlands include the soil map prepared by Johannesson (1960; see explanations by Arnalds $2015 \mathrm{Ch} .7$ ), yielding $9-10,000 \mathrm{~km}^{2}$ of what he termed 'peatlands'. However, wetlands of various organic content are a more appropriate term as is explained in the section on soils below. This mapping was a noteworthy attempt, yet with relatively high uncertainty as the map is highly generalized with a very coarse scale $(1: 750,000)$. Other complete overviews include a vegetation map with the scale of 1:500,000 by the Icelandic Museum of Natural History (Gudjonsson and Gislason 1998) and the CORINE coverage, which is in large part a simplified version of the Agricultural University of Iceland (AUI) data presented here. 
a
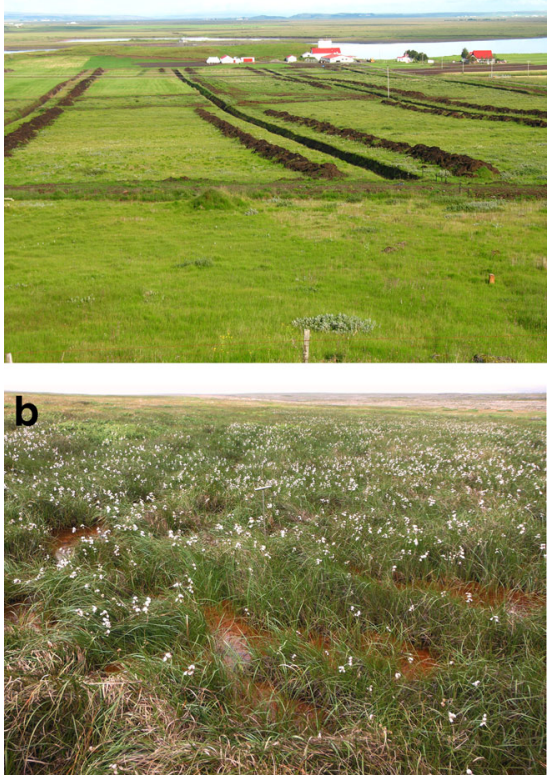

Fig. 1 a Typical Icelandic agricultural landscape. Hay fields are located between the ditches (photo A.L. Aradottir): b Undisturbed wetland patch. Vegetation dominated by Eriophorum angustifolium. Reduced iron (blue) and bog iron (reddish brown) present in the water. Many of the wetlands have frequently occurring gradients from wet to dry. Salix is present at the edge of this patch (upper left) in damp wetland. Typical highland landscape with mosaic of vegetation and soil types, including barren areas (deserts, upper right)

\section{Materials and Methods}

The geographical data applied for the spatial analyses were derived from three main sources: the Agricultural University of Iceland (AUI) Nytjaland and IGLUD databases and the AUI soil map and soil databases. The AUI hosts several national geographical databases which include a soil database and a map, a database for broadly defined vegetation classes (Icelandic Farmland Database, Nytjaland in Icelandic) and the IGLUD (Icelandic Geographical Land Use Database), which was constructed in response to Iceland's commitments to the UN Framework Convention on Climate Change (UN FCCC; Gudmundsson et al. 2013). The Nytjaland database was made from supervised classification of Landsat 7 and Spot 5 satellite images, covering all of Iceland. Most of the work entailed separating the land into 10 vegetation classes, in addition to ice/glaciers and water/sea, but for a proportion of the country, 6 vegetation classes were used. The database was described in detail by Gisladottir et al. (2014) in Icelandic, but also in part in English by Arnalds and Barkarson (2003). The IGLUD database land use map of Iceland is compiled annually from a large number of available map layers, including the Nytjaland classification. The ditch network was digitized at the AUI manually using aerial and satellite photographs. Data on cultivated land (hay fields) were also assembled by digitizing the areas. The IGLUD database and its preparation was described by Gudmundsson et al. (2013) and Wöll et al. (2014). The soil map was constructed by combining soil metadata housed by the AUI (Ymir database) and the Nytjaland land cover database (Arnalds and Oskarsson 2009). This is a rather broad scale map $(1: 250,000)$ for general overview of the soils of Iceland.

The extent of wetlands and drainage was estimated using the AUI Nytjaland and IGLUD databases. Two main classes of the Nytjaland classification encompass wetlands: "saturated wetlands" and "damp wetlands". The IGLUD map layer of areas affected by drainage represent areas with average drawdown of the water table of $>15 \mathrm{~cm}$, which is, however, subjected to seasonal and annual differences. The preparation of the map layer of drained soils is based on a maximum $200 \mathrm{~m}$ distance from ditches. Other vegetation classes closer to $200 \mathrm{~m}$ distance from ditches are excluded, as well as areas of more than $10^{\circ}$ slope. Areas $<200 \mathrm{~m}$ from a ditch but isolated from it by a body of water are excluded from affected areas. The $200 \mathrm{~m}$ distance is based on considerable efforts by AUI to categorize drainage impacts (mostly unpublished data, see also Oskarsson 1998; Gisladottir et al. 2007, 2010; Gisladottir and Oskarsson 2011). The preparation of the map layer for drained soils has been further described by Wöll et al. (2014). Map layers for croplands (mostly hay fields) on wetland soils were made separately based on surveys of croplands and time series of land use conversions as described by Wöll et al. (2014). All data layers were combined to prevent overlapping or double counting of areas.

The impacts range from subtle changes in water flow, habitat diversity and nutrient and greenhouse gas dynamics (lowest density) to substantial lowering of the water table with pronounced releases of greenhouse gasses and vegetation changes, but many of the areas are also subjected to plowing (hay-making) and intensive grazing that cause ecosystem changes on top of changes caused by the drainage.

Levels of disturbance were estimated by using a kernel density method to calculate accumulated ditch density for areas closer than $200 \mathrm{~m}$ from a ditch. Then the impacted area was grouped into the following density intervals: $0.1-5,5-10$, $10-15,15-20$, and $>20 \mathrm{~km} \mathrm{~km}^{-2}$. Areas of slopes $>10^{\circ}$, poorly vegetated land and road beds were excluded in the process. In addition, the size distribution of the inland wetlands in the AUI databases was determined, using the following size categories: $<1,1-5,5-50,50-100,100-500$ and $>500$ ha.

\section{The Inland Wetlands: Soils, Vegetation and Birds}

\section{Soils}

Most circumpolar areas of similar latitudes, such as in Finland, Russia, Alaska and Canada, have extensive wetlands of high organic content (peat), often dominated by permafrost (Jones et al. 2010). The mixture of poorly crystalline basaltic volcanic 
materials and peat, which dominates Icelandic wetland soils, is uncommon in the world, judging from our literature search. They differ from the paramo Histic Andosols of Ecuador (Buytaert et al. 2005, 2007) and the Azores (Madeira et al. 2007) in having a lower content of metal-humus complexes and a higher proportion of vitric materials deposited by continuous re-distribution of volcanic ash materials. The Icelandic wetland soils rarely exhibit hydric soil properties ( $>100 \%$ water content at 15 bar tension) in contrast to more developed Hydric Andosols of warmer climates. Aquic Andosols have been reported in many areas such as Japan (e.g., Shoji and Ono 1978), however usually much more developed and lacking the frequent volcanic additions and continuous aeolian deposition of volcanic ash which give the Icelandic soils their distinctive young and vitric character.

The soils of Icelandic inland wetlands have a wide range of organic content in the surface horizons that determine the classification of the soils. The $\mathrm{C}$ content is most often $<25 \%$, considerably lower than the $36-54 \% \mathrm{C}$ averages reported by Loisel et al. (2014) for northern peatlands. The soils of palsa areas (permafrost mounds) also have low organic content in surface horizons in contrast to most other Arctic palsa areas (Saemundsson et al. 2012). Carbon accumulation in the Icelandic soils, based on data from Oskarsson et al. (2004) and averaging total carbon stocks over 8000 yrs. indicates accumulation from $4 \mathrm{~g} \mathrm{~m}^{-2} \mathrm{yr}^{-1}$ (Gleyic Andosols) to $25 \mathrm{~g} \mathrm{~m}^{-2} \mathrm{yr}^{-1}$ (Histosols). The accumulation in Histosols is of the same order as $23 \mathrm{~g} \mathrm{~m}^{-2} \mathrm{yr}^{-1}$ reported for northern peatlands by Loisel et al. (2014). Gudmundsson (2008) studied reported carbon accumulation between tephralayers of known age for a Histosol in NW Iceland. The accumulation ranged between 9 and $20 \mathrm{~g} \mathrm{~m}^{-2} \mathrm{yr}^{-1}$ during the Holocene ( 4 periods) with the average rate of about $15 \mathrm{~g} \mathrm{~m}^{-2} \mathrm{yr}^{-1}$.

An Icelandic soil classification system (Arnalds and Oskarsson 2009) separates the inland wetland soils based on carbon content in the top $30 \mathrm{~cm}$ into Gleyic Andosols $(<12 \%$ C), Histic Andosols (12-20\% C) and Histosols (>20\% C). Andosols, by nature, accumulate higher organic content than other mineral soils and are differentiated from Histosols according the US Soil Taxonomy (Soil Survey Staff 1999) and the WRB (IUSS Working Group WRB 2014) at the $25 \%$ C level (not $12-16 \%$ as for the difference between Histosols and other mineral soils). These soils differ from the highly peaty Arctic soils, as they have a higher $\mathrm{pH}$ (often $>5$ ) and $\mathrm{C} / \mathrm{N}$ ratio of $13-$ 25 , noticeably lower than the 34-77 average range reported for northern and Arctic peatlands (Loisel et al. 2014). Considerable amounts of nitrogen become readily available upon drainage. Part of the organic matter in all the wetland soils is in the form of organo-mineral complexes, which are characteristic of volcanic soils in general (see Arnalds 2015 Ch. 8). The variability in carbon content of Icelandic wetland soils is in large part due to differences in aeolian and tephra deposition contributing mineral matter to the soils, with substantially lower organic content close to volcanoes and the major dust sources. Variability in organic content is also caused by differences in drainage, flooding regimes and landscape positions (Arnalds 2004; Arnalds and Oskarsson 2009). Gleyic Andosols (Fig. 2) with relatively low organic content (often 2-6\%) are dominant within the active volcanic zone, but there is a gradient with carbon content gradually becoming higher with distance from active dust sources and volcanoes. Highly organic soils are therefore mostly found far away from active dust sources such as in West, Northwest and North Iceland. The main characteristic of the organic matter in the soils is that it is poorly decomposed and the Histosols would classify as Fibrists (Borofibrists and Cryofibrists) under Soil Taxonomy. They show considerable shrinkage when they are completely dried in the laboratory (often less than $1 / 2$ of the original volume when dry), but limited or very slow shrinkage in the field when drained, which is in part attributed to the volcanic ash materials in the matrix (Bartoli and Burtin 2007).

The Gleyic Andosols contain 10-20\% clays (allophane and ferrihydrite) on average, while the Histosols do not contain appreciable amounts of clays with Histic Andosols being intermediate. There is a gradient in $\mathrm{pH}$ from Gleyic Andosols (6-7) through Histic Andosols (5-6) to Histosols (4-5) attributable to decreasing aeolian input and increased organic content (Arnalds $2015 \mathrm{Ch}$. 8). Bulk density ranges from 0.2 in organic horizons to about $0.7 \mathrm{~g} \mathrm{~cm}^{-3}$ in mineral horizons in Gleyic Andosols. The organic horizons have higher water retention than would be expected, but so do also the mineral horizons due to their andic soil properties (see Arnalds 2004,

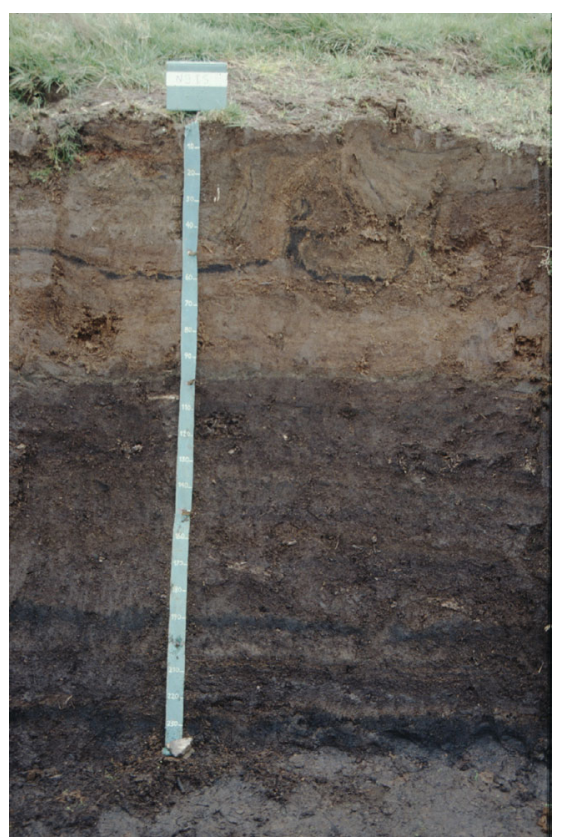

Fig. 2 Typical Gleyic Andosol, showing distinct tephra layers and signs of cryoturbation in the upper horizons. The boundary between the lighter colored upper part and darker colored lower part of the profile marks the settlement of Iceland about 1200 yrs. ago. Increased aeolian activity consisting in part of re-distribution of light colored tephra fragments influences the soil color. The lower part is more organic $(>13-20 \% \mathrm{C})$ while the upper part has about $10 \%$ C; see Arnalds 2015 Ch. 8) 
$2015 \mathrm{Ch} .7)$. The depth of the Icelandic inland wetland soils is quite variable, ranging from a few $\mathrm{cm}$ to several meters, but commonly $1-3 \mathrm{~m}$.

\section{Vegetation}

The vegetation of Icelandic wetlands was described by Steindorsson (1964), but Magnusson (1998) specifically addressed the plants of drained wetlands. The overarching characteristic of Icelandic wetland vegetation is the predominance of vascular plants and virtual absence of Sphagnum moss dominated wetlands. This can most likely be ascribed to the general fertility of these systems arising both from the widespread aeolian deposition of mineral matter and the fact that there are almost no truly ombrotrophic inland wetlands in Iceland, most being minerotrophic or only partially ombrotrophic (Steindorsson 1964). Drainage changes the systems from minerotrophic to ombrotrophic in areas closest to the ditch.

The subsequent discussion takes note of the Agricultural University databases which separate the wetlands into "saturated wetlands" and "damp wetlands". Other divisions of Icelandic wetlands are discussed in Olafsson (1998). The plant species characteristic of the "saturated wetland" class include various Carex spp., such as Carex bigelowii, C. lyngbyei, C. rostrata, C. chordorrhizia, and Equisetum spp. Cotton grass (Eriophorum angustifolium) is quite common as are some heathland species such as dwarf-birch (Betula nana), blueberries (Vaccinium uliginosum), crowberries (Empetrum nigrum), common heather (Calluna vulgaris) and Arctostaphylos uva-ursi, but also willow species (Salix phylicifolia, S. arctica and S. lanata). Moss species of the genera Hypnum, Philonotis, Mnium and Rachometrium are widespread. Species characteristic of damp wetlands include many of the same species found in saturated wetlands, with lower dominance of Carex spp. and more frequent occurrence of woody species.

\section{Birds}

Icelandic wetlands in general are particularly important for birds with approximately $75 \%$ of Icelandic bird species relying in part or fully on various types of wetlands as a habitat (Gudmundsson 1998). The Icelandic wetlands (including the inland fens) support about 20 internationally important bird species (Einarsson et al. 2002). They are of particular importance for waders (Charadrii) in the northern hemisphere (Gunnarsson et al. 2006). Wetland birds include golden plover (Pluvialis apricaria), dunlin (Calidris alpina), snipe (Gallinago gallinago), whimbrel (Numenius phaeopus), black-tailed godwit (Limosa limosa), redshank (Tringa totanus), and meadow pipit (Anthus pratensis). Swans (Cygnus cygnus) and geese are also common, including the graylag goose (Anser anser) and pink-footed goose (Anser brachyrhynchus). Some of the highland wetlands are of particular importance, e.g., the Thjorsarver RAMSAR area, the world's largest breeding ground of pink-footed goose.

\section{History of the Drainage Effort}

Draining wetlands facilitates oxidation of organic matter and release of nutrients, resulting in substantial increase in biomass production (Magnusson 1998), at least in the short-term. This prospect was of interest to the farming community during the early twentieth century. A law was passed in 1923 that initiated subsides for draining. Minor areas were drained annually during the first few decades as ditches were excavated by hand. After World War II, with the arrival of large and effective machinery for excavation, a broad-scale draining of the wetlands was initiated. The drainage activity gained momentum relatively rapidly, expedited by the government subsidies (Fig. 3). The draining peaked in 1968, when $1633 \mathrm{~km}$ of ditches were excavated. The effort decreased considerably after 1987 (Bjarnason 1982; Snaebjörnsson et al. 2010), when subsidies were cut dramatically, but it can also be postulated that much of the easily drained land near the farmsteads had been drained by that time. About $15 \%$ of the drained wetlands are used for hay-making. The drained areas are also used for grazing to some extent. However, some of the drained land is not used for agriculture; the draining disturbance of those areas has no practical purpose.

\section{Results}

\section{The Extent of inland Wetlands}

The wetlands, as represented in the AUI databases, consist of three classes: the saturated wetlands, damp wetlands and drained wetlands (partial to fully). The spatial distribution of these wetlands is presented in Fig. 4, and their altitudinal distribution is presented in Table 1.

The results of this GIS based analysis indicate that Icelandic inland wetlands cover about $9000 \mathrm{~km}^{2}$. This area is based on vegetation classification using satellite images, with open water reflectance signals to augment the classification. It is likely that soil-based classification reflecting the presence of shallow ground water would increase this extent. However, data are not available at this time.

Wetlands occur in all geographic regions of Iceland and extend into highland elevations. However, about two-thirds of the wetlands are found below $200 \mathrm{~m}$ elevation, or $5795 \mathrm{~km}^{2}$, which is equivalent to approximately $23 \%$ of the lowland surface area and about $31 \%$ of the vegetated land occurring below $200 \mathrm{~m}$. About $20 \%$ of wetlands are located between 200 and $400 \mathrm{~m}$ elevation, but their extent falls dramatically at higher elevations as does vegetation cover in general. Prominent inland fen wetlands occupy the southern lowlands (Fig. 4), with mostly 
Fig. 3 Cumulative and annual ditch excavation with time. The majority of ditches were excavated prior to 1987 , with annual activity peaking in 1968 $\left(>1600 \mathrm{~km} \mathrm{yr}^{-1}\right)$

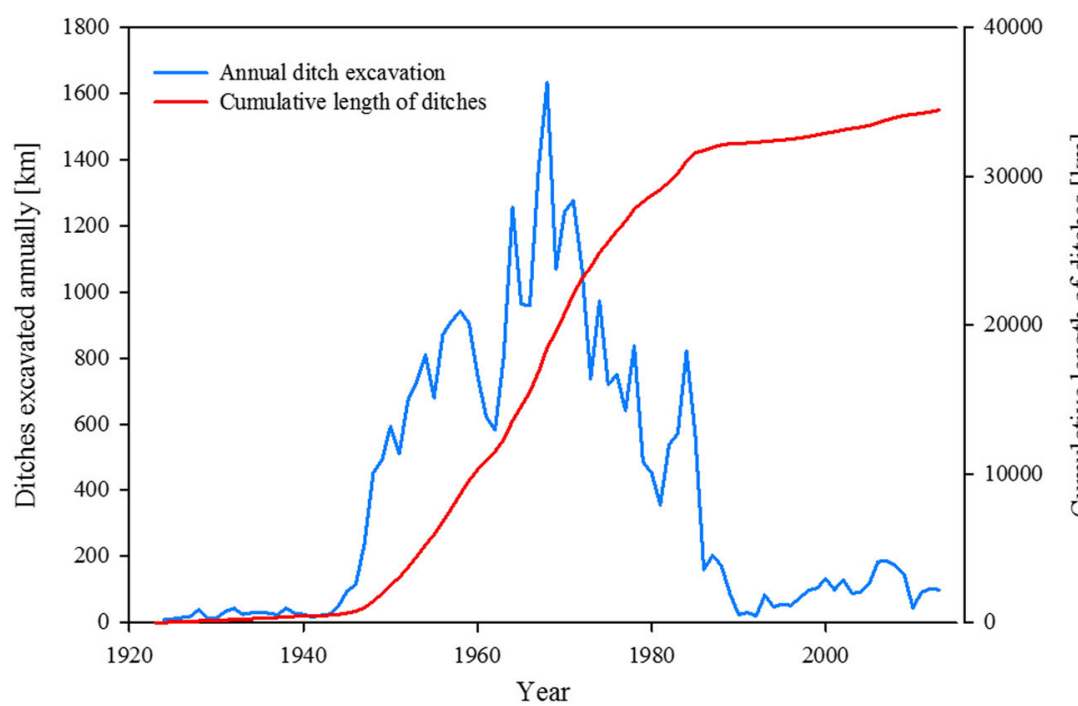

inorganic Gleyic Andosols in the eastern part where aeolian and volcanic ash inputs are relatively high, together with Histic Andosols and higher carbon content towards the western part of the southern lowlands (Fig. 4). Prominent inland wetlands also occupy western Iceland, mainly Histosols and Histic Andosols. Inland wetlands are also common within the deep valleys of the Tertiary Formation in North and West Iceland, harboring mostly Histic Andosols and Histosols. Widespread wetlands are found in the northwestern and eastern highlands (Fig. 4).

\section{Drainage Disturbance}

Our results show that $4195 \mathrm{~km}^{2}$ or $47 \%$ of all Icelandic inland wetlands have been impacted by drainage (Table 1), ranging from full drainage to subtle changes in water levels. The table shows only areas affected by draining (see Materials and
Methods), but limited data are available for other wetland disturbances, except for hydro-electric reservoirs. The majority $(70 \%)$ of the lowland wetlands below $200 \mathrm{~m}$ elevation have been affected. Drainage of inland wetlands is rather limited above $200 \mathrm{~m}$ elevation, coinciding with the much limited agriculture at higher elevations.

\section{Ditches and Ditch Density}

The digitization of the entire ditch system revealed a total of about 29,700 km of ditches (see also Gisladottir et al. 2010). Preliminary results from a survey on the accuracy of the digitation showed that $91 \%$ of ditches mapped were confirmed as ditches and that $5 \%$ of ditches had gone undetected by the mapping effort (Wöll et al. 2014). This estimate of the total length of ditches is slightly lower than the previous estimate of
Fig. 4 Inland wetlands in Iceland. The most prominent areas are the southern and western lowlands together with the NW and NE highlands. Major wetland soil types dominating each region are indicated, enclosed by dotted lines. H: Histosols, HA: Histic Andosols, and G: Gleyic Andosols. Ramsar sites are indicated as green areas. The majority of the lowland wetlands have been impacted by drainage. Some impacted wetlands with altered vegetation cover and/or agricultural fields are not shown. Large water bodies are shown in blue. White areas on the map represent glaciers

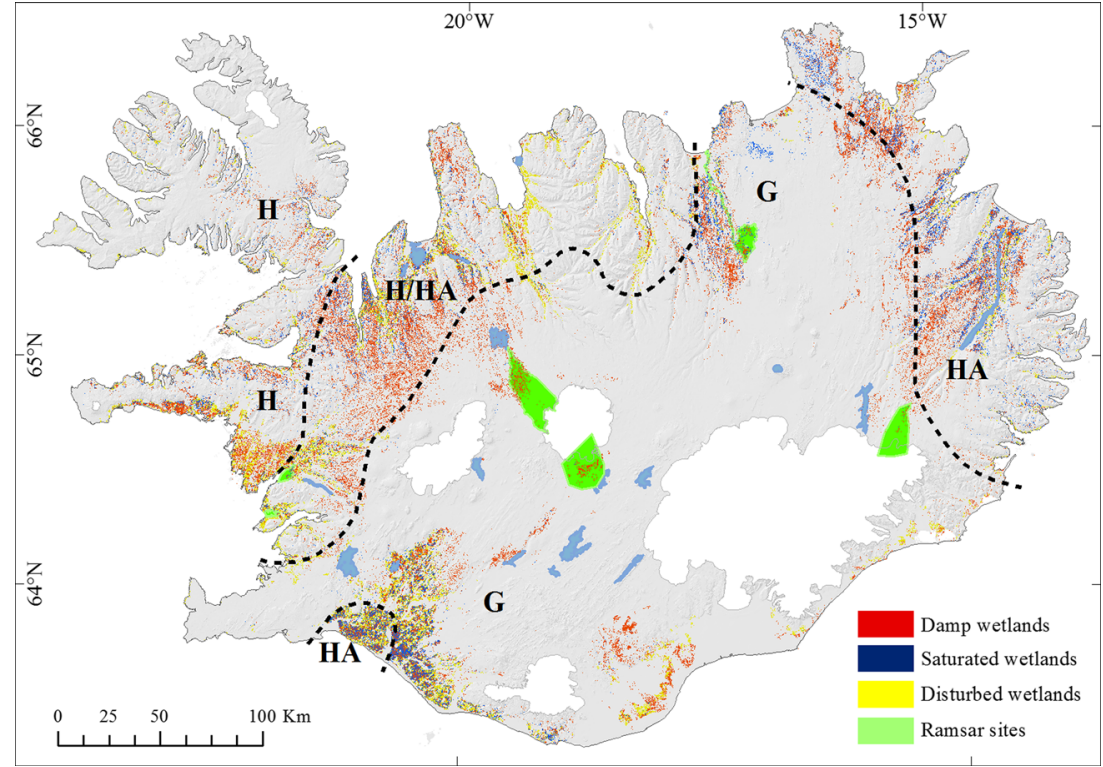


Table 1 A geographical summary for Icelandic inland fen wetlands, sorted by elevation intervals. Wetlands are separated into saturated and damp wetlands. Total vegetation cover is shown in the top row for comparison. Data from the IGLUD database which is based in part on the Nytjaland database

\begin{tabular}{|c|c|c|c|c|c|c|c|}
\hline & \multicolumn{7}{|l|}{ m.a.s.l. } \\
\hline & $0-200$ & $200-400$ & $400-600$ & $600-800$ & $800-1000$ & $>1000$ & Total \\
\hline & \multicolumn{7}{|l|}{$\mathrm{km}^{2}$} \\
\hline Total area & 25,257 & 18,106 & 22,293 & 18,519 & 8345 & 10,163 & 102,683 \\
\hline Vegetated land & 18,665 & 12,758 & 10,550 & 3932 & 385 & 41 & 46,331 \\
\hline Undisturbed wetlands $\$$ & 1743 & 1611 & 1175 & 258 & 2 & 0 & 4789 \\
\hline Saturated wetlands & 1112 & 1170 & 1010 & 236 & 2 & 0 & 3529 \\
\hline Damp wetlands & 631 & 441 & 166 & 23 & 0 & 0 & 1260 \\
\hline Drained wetlands & 4052 & 136 & 3 & 0 & 0 & 0 & 4191 \\
\hline \multirow[t]{2}{*}{ Total wetlands } & 5795 & 1747 & 1178 & 258 & 2 & 0 & 8980 \\
\hline & \multicolumn{7}{|l|}{$\%$} \\
\hline Impacted wetlands & 69.9 & 7.8 & 0.3 & 0 & 0 & 0 & 46.7 \\
\hline
\end{tabular}

$\$$ Saturated wetlands + damp wetlands in the table

Geirsson (1975), who estimated the total length of drainage ditches to be $32,700 \mathrm{~km}$ based on records of excavated volume obtained in relation to the subsidies rendered for making the ditches. The ditch system is further augmented by $61,600 \mathrm{~km}$ of sub-surface drainage made in 1961-1993, mostly in areas where ditches are in place (Geirsson 1975; Helgadottir et al. 2013).

The majority of the impacted area has low accumulated ditch density (0.1-0.5 $\mathrm{km} \mathrm{km}^{-2}$; Table 2) i.e. about $2300 \mathrm{~km}^{2}$, or $67 \%$. The highest densities of $>10 \mathrm{~km} \mathrm{~km}^{-2}$ make up $309 \mathrm{~km}^{2}$ of the impacted area. The total extent of cultivated areas (hay-fields and other crops) in Iceland is about $1290 \mathrm{~km}^{2}$, of which about half is on drained wetland soils (Wöll et al. 2014; see also Helgadottir et al. 2013).

An example of an area with extensive wetland draining in South Iceland is provided in Fig. 5. The figure shows that almost the entire area is influenced by the draining, which is in accordance with the results for areas $<200 \mathrm{~m}$ elevation in general. The hayfields and other cultivated land are within the areas of the highest drainage densities next to the farms. Many areas shown as intact in the figure are encircled by a ditch system and are likely to be somewhat impacted. Undisturbed areas are found on the riverine floodplains. The impacts of low ditch densities are also affected by landscape characteristics such as slope and bedrock hydrology. It is clear that a large proportion of the drained land is not used for such agricultural production. An undefined, but substantial proportion of the remaining drained wetlands is used for periodic grazing (data not available), and some are used for afforestation.

\section{Wetland Patch Size}

The majority of the fragmented wetland patches are small or below one ha in size (Table 3), with over one million such patches registered in our GIS Nytjaland database and accounting for about $30 \%$ of the wetland areas. Damp wetland patches are smaller on average than the saturated wetland patches (data not shown). Only $16 \%$ of the wetlands occur as patches $>100$ ha $\left(1 \mathrm{~km}^{2}\right)$. Larger patches occur as saturated wetlands on average compared to damp wetlands, which indicates that there is a higher probability of saturated surface conditions within the larger wetland patches. Damp wetlands are often found at the periphery of the saturated wetlands and are therefore relatively smaller than continuous saturated wetland patches.
Table 2 Wetland disturbance by drainage sorted by density of ditches

\begin{tabular}{lllll}
\hline $\begin{array}{l}\text { Density } \\
\mathrm{km} \mathrm{km}^{-2}\end{array}$ & $\begin{array}{l}\text { Length of ditches } \\
\mathrm{km}\end{array}$ & $\begin{array}{l}\text { Impacted areas } \\
\mathrm{km}^{2}\end{array}$ & $\begin{array}{l}\text { Proportion of ditches } \\
\%\end{array}$ & Proportion of total \\
\hline $0.1-5$ & 1818 & 2300 & 6.1 & 66.6 \\
$5-10$ & 11,462 & 858 & 38.6 & 24.7 \\
$10-15$ & 8479 & 231 & 28.6 & 6.7 \\
$15-20$ & 5337 & 63 & 18.0 & 1.8 \\
$>20$ & 2585 & 15 & 8.7 & 0.4 \\
Total & 29,680 & 3468 & 100 & 100 \\
\hline
\end{tabular}


Fig. 5 Drained area in South Iceland. The river Thjórsá, partly in a gorge, runs through the center of the image. Undisturbed saturated and damp wetlands shown separately. The black lines display the ditch network. The map shows clearly that most of this area is less than $200 \mathrm{~m}$ from ditches, but a relatively small proportion of the area is cultivated (hay fields). Some areas marked undisturbed are surrounded by ditches but $>200$ from them. These areas are mostly likely somewhat impacted by the drainage, but the numbers for impacted areas are not included

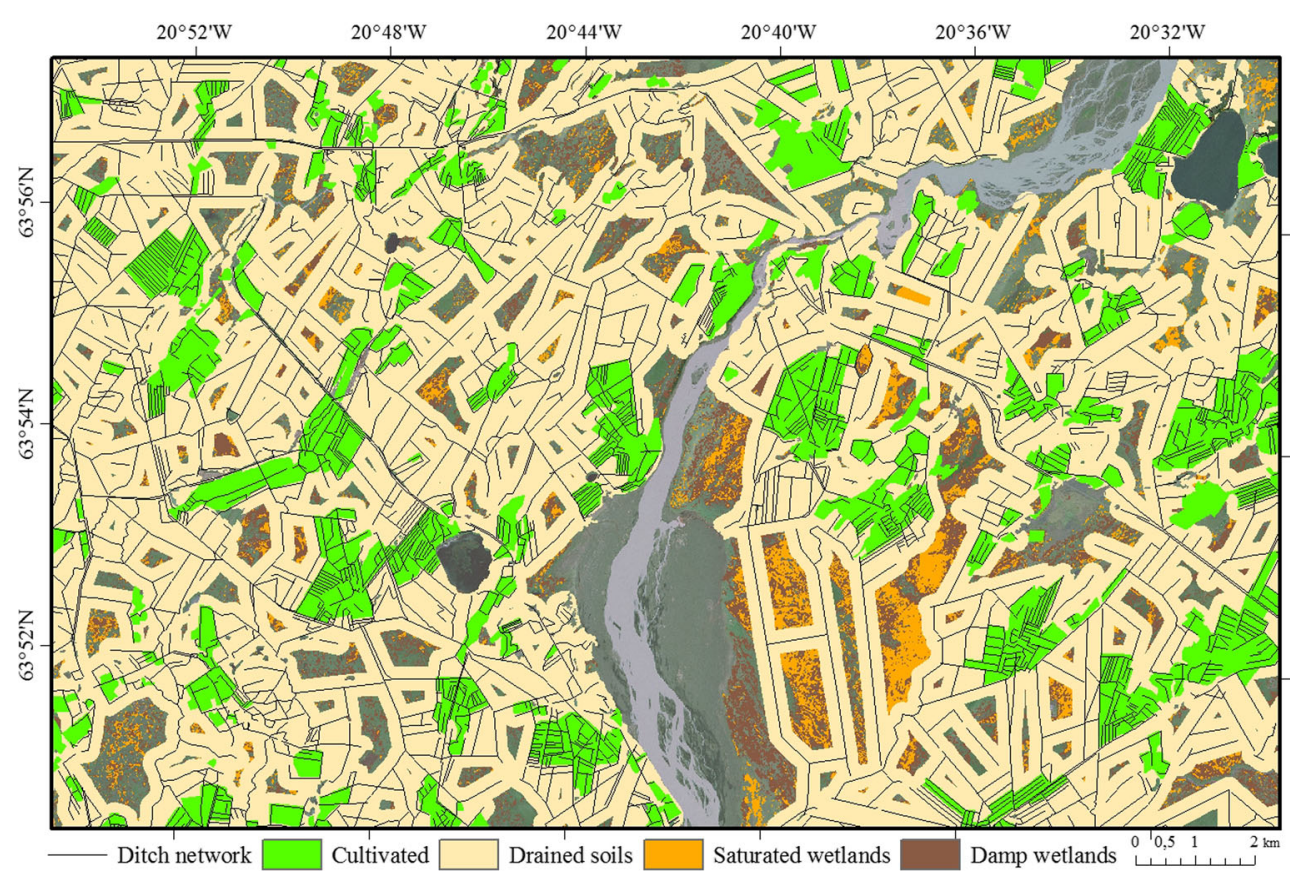

\section{Discussion}

The soils of Icelandic wetlands are exceptional on a global scale for being a mixture of volcanic and organic soils, with extremely variable organic content. Their carbon content is usually much lower than in Arctic wetland soils (especially the Gleyic Andosols) and the $\mathrm{C} / \mathrm{N}$ ratio is lower. They are more vitric in character than much of the Aquic and Hydric Andosols found in other volcanic areas. Their fertility is enhanced by a relatively favorable $\mathrm{pH}$ maintained by nutrient release from the rapid weathering of basaltic volcanic glass (see Arnalds 2008, 2015 Ch. 9). Their uniqueness is highlighted by their dissimilarity with other northern circumpolar soils, which mostly constitute peat soils (Histosols) and/or Cryosols (permafrost) (Jones et al. 2010), while Icelandic wetlands are dominated by Andosols (mineral soils with variable organic content) with a relatively small proportion of Histosols, which also are influenced by aeolian deposition of volcanic materials.

Table 3 Number of wetland patches sorted by patch size for saturated wetlands and damp wetlands. Data from the Nytjaland AUI database and includes some disturbed/impacted wetlands

\begin{tabular}{llll}
\hline Patch size (ha) & Number of areas & Combined area $\left(\mathrm{km}^{2}\right)$ & $\%$ \\
\hline$<1$ & $1,135,626$ & 1631 & 29.6 \\
$1-5$ & 61,859 & 1225 & 22.2 \\
$5-50$ & 11,768 & 1446 & 26.2 \\
$50-100$ & 486 & 334 & 6.1 \\
$100-500$ & 318 & 588 & 10.7 \\
$>500$ & 29 & 288 & 5.2 \\
\hline
\end{tabular}

The results show that a substantial part of the Icelandic inland wetlands have been disturbed by drainage. About $47 \%$ of Icelandic wetlands have been drained, mostly below $400 \mathrm{~m}$ elevation. The results show that $70 \%$ of the inland wetlands below $200 \mathrm{~m}$ elevation have been impacted to some degree, which is in good accordance with research on the southern and western lowlands (Thorhallsdottir et al. 1998; Oskarsson 1998). We suggest that the motivations for many of the ditches of the lowest densities $\left(<10 \mathrm{~km} \mathrm{~km}^{2}\right)$ were subsidy driven rather than by need for agricultural land, but such claims are difficult to corroborate.

The areas of intense drainage most often go through a vegetation composition shift from wetland to grassland plant communities, with higher cover of graminoids with various amounts of salix species and herbaceous plants, but the shift is also dependent on land use, such as grazing and fertilizer use, which tend to increase the abundance of grasses (see Magnusson 1998). We recognize that our estimate based on the $200 \mathrm{~m}$ distance from a ditch has its limitations. This distance is an estimated average, but will vary from one area to the other. Areas beyond the $200 \mathrm{~m}$ range enclosed by ditches, a common scenario in South Iceland, are also most likely impacted, with altered water and nutrient flows. This methodology gives a good first appraisal of drainage impacts in Iceland.

A minor proportion of the drained land (15\%) is used for hay production, mostly of high density drainage. Grazing by horses on both drained and undrained lowland wetlands has caused damage to the vegetative cover in many places (Magnusson 1998). The highland ecosystems are not affected by drainage efforts. They often feed important salmon rivers that have a significant impact on the rural economy. However, some highland wetlands have been disturbed by hydropower 
development, such as in the Blanda and Kárahnúkar areas in Northwest and East Iceland. There is widespread livestock grazing (mostly sheep) in the highlands, which has influence on wetlands, especially damp wetlands, which is likely to alter species composition, but research on these impacts is limited. Other disturbances have not been surveyed to date. It should also be noted that the nature of many of the inland wetlands, both highland and lowland, has been altered by increasing aeolian deposition rates after the Settlement of Iceland about 1200 years ago, with reduced carbon content per depth increment and often altered hydrology resulting from coarse sediments (silt and sand) being deposited on the areas.

The carbon dioxide emissions from drained wetlands outside cultivated areas are calculated as $5100-10,600 \mathrm{Gg} \mathrm{CO}_{2}$ (data from Gudmundsson and Oskarsson 2014), or $7300 \mathrm{Gg}$ $\mathrm{CO}_{2}$ by applying the IPCC default emission factor for the area. The emissions of other greenhouse gasses $\left(\mathrm{N}_{2} \mathrm{O}, \mathrm{CH}_{4}\right)$ and off-site emissions are not included but add about $2300 \mathrm{Gg}$ $\mathrm{CO}_{2}$ equivalents to the greenhouse gas impact of drainage (Hellsing et al. 2016). These emissions exceed the sum of all Icelandic non-LULUCF emissions (including smelters and transportation) reported for the year 2014 for Iceland (4597 $\mathrm{Gg} \mathrm{CO}_{2}$ equivalents) (Hellsing et al. 2016).

Icelandic landscapes are characterized by a great variety of ecotypes over short distances and this is reflected by the large number of small wetland patches. Small patches are important in terms of ecological functions and biodiversity, with a wide range of habitats provided over relatively short distances, while the small wetland patches also provide improved hydrological characteristics such as water regulation during snow melt on a landscape level. Small-scale mosaics of different habitat types can better fulfill different requirements for birds during the breeding season (e.g. nesting, feeding) than larger homogenous areas (Gunnarsson et al. 2006; Pickett and Siriwardena 2011; Benton et al. 2003). Our results show that much of the inland wetland patches are $<5$ ha with about $30 \%$ of wetland areas consisting of patches smaller than $1 \mathrm{ha}$. Only a proportion of the small damp wetland patches were created by the drainage activities in areas below $200 \mathrm{~m}$ elevation. The importance of patch size is reflected in the current law, stating that wetland areas $>3$ ha in size should not disturbed. The 3 ha reference is based on much coarser mapping than presently available and potentially concealing the importance of smaller patches. The results presented here suggest that it is important to protect areas characterized by small wetland patches which give rise to the importance of the ecosystem mosaic rather than isolated habitat types and thus, small wetland patches are quite important. We argue that there should be adopted a smaller reference size than the current 3 ha (e.g. 0.5 ha) in light of the importance of the small wetland patches in the overall ecosystem mosaic. Further analysis of the $1-5$ ha patch size shows that $>40 \%$ of wetland the area within this size class is between 1 and 2 ha. About $55 \%$ of remaining wetlands are currently excluded from any protection.

\section{Conclusions}

Icelandic inland wetlands are among the most important ecosystems of the country because of their role in biodiversity, water regulation and carbon budgets and they have an international value by supporting large populations of migratory bird species. There is a need for increased research on the hydrology of Icelandic wetland soils and the impact of draining. Furthermore, there is a need to analyze the relationship between drainage levels and impacts on various ecosystem factors and processes, such as fragmentation, GHG budgets, nutrient cycling and release, bird life, plant composition and other biotic factors. Research on biodiversity in relation to wetlands also needs more attention in future studies.

The remaining undisturbed inland wetlands are still being threatened by such factors as agriculture, with improved crop growing conditions with the current warming of the climate (see Helgadottir et al. 2013), development and subdivision, land fragmentation (see Wald 2012), afforestation efforts and the generation of hydropower (large reservoirs). Some sectors, including the road authorities, have adopted strict policies to avoid wetland disturbance or restoring wetlands in place for wetland areas deemed necessary to disturb (Stefansdottir 2011). We conclude that it is important to increase the level of protection of all wetlands in Iceland. Lists have been made of areas in need of protection based on the importance to bird ecology (Ferdinand et al. 1973). The databases presented here have been shown to be of value for predicting wetland bird species and densities (Johannesdottir et al. 2014; Gunnarsson et al. 2015). Many wetlands are on a list proposed for nature protection ("Náttúruminjaskrá", Icelandic Natural Features Database, kept by the Environmental Agency of Iceland). However, there is a need to strengthen work to systematically prioritize the protection and restoration of Icelandic wetlands, which considers a broad range of factors such as size, continuity, ecology, hydrology, geomorphology, and the uniqueness of the wetlands on national, regional and global scales.

Open Access This article is distributed under the terms of the Creative Commons Attribution 4.0 International License (http:// creativecommons.org/licenses/by/4.0/), which permits unrestricted use, distribution, and reproduction in any medium, provided you give appropriate credit to the original author(s) and the source, provide a link to the Creative Commons license, and indicate if changes were made.

\section{References}

Arnalds O (2004) Volcanic soils of Iceland. Catena 56:3-10

Arnalds O (2008) Soils of Iceland. Jökull - The Icelandic J Earth Sci 58: $409-421$

Arnalds O (2015) The soils of Iceland. World Soils Book Series. Springer, Dordrecht, the Netherlands 
Arnalds O, Barkarson BH (2003) Soil erosion and land use policy in Iceland in relation to sheep grazing and government subsidies. Environ Sci Pol 6:105-113

Arnalds O, Oskarsson H (2009) Soil map of Iceland. Náttúrufræðingurinn 78:107-121 (In Icelandic, English summary, table and figure legends)

Bartoli F, Burtin G (2007) Organo-mineral clay and physical properties in COST-622 European volcanic soils. In: Arnalds O, Bartoli F, Buurman P, Oskarsson H, Stoops G, Garcia-Rodeja E (eds) Soils of volcanic regions in Europe. Springer, Heidelberg, Germany, pp. 469-491

Benton TG, Vickery JA, Wilson JD (2003) Farmland biodiversity: is habitat heterogeneity the key? Trends Ecol Evol 18:182-188

Bjarnason B (1982) Saga vatnsveita og framræslu (The story of water diversions and drainage). In: Snaebjornsson A (ed) Pættir um mýrajarðveg á Íslandi, Agricultural College Report 38:3-7. Agricultural College (now Agricultural University of Iceland), Hvanneyri, Iceland

Buytaert W, Wyseure G, De Bièvre B, Deckers J (2005) The effect of land-use changes on the hydrological behaviour of Histic andosols in South Ecuador. Hydrol Process 19:3985-3997

Buytaert W, Deckers J, Wyseure G (2007) Regional variability of volcanic ash soils in South Ecuador: the relation with parent material, climate and land use. Catena 70:143-154

Cowardin LM, Carter V, Golet FC, LaRoe ET (1979) Classification of wetlands and Deepwater habitats of the United States. U. S. Department of the Interior, Fish and Wildlife Service, Washington, D.C.

Ehlmann BL, Bish DL, Ruff SW, Mustard JF (2012) Mineralogy and chemistry of altered Icelandic basalts: Application to clay mineral detection and understanding aqueous environments on Mars. J Geophys Res 117:E00J16. doi:10.1029/2012JE004156

Einarsson Ó, Kristinsson H, Skarphéðinsson KH, Ottósson JG (2002) Verndun tegunda og svæða: tillögur Náttúrufræðistofnunar Íslands vegna Náttúruverndaráætlunar. The Icelandic Institute of Natural History. Reykjavik, Iceland (In Icelandic)

Ferdinand FHM, Thamdrup A, Haapanen H, Ormio CH, Ovesen A, Gardarson D (1973) Oversigt over vigtige våde fugleområder $i$ Norden. Nordiske arbejdsgruppe vedrørende beskyttelse af våde fugleområder "wetlands". Copenhagen, Denmark, 366 pp

Gardarsson A (1998) Íslensk votlendi (Icelandic wetlands). In: Olafsson JS (ed) Icelandic Wetlands, Protection and Utilization (Íslensk votlendi, verndun og nýting). Háskólaútgáfan (University Publishing). University of Iceland, Reykjavik, pp. 13-35

Geirsson O (1975) Framræsla (Bog drainage for farming purposes). In: Garðarsson A (ed) Íslensk votlendi (Icelandic Wetlands). Landvernd Publ. no 4. Icelandic Environment Association, Reykjavik Iceland, pp. $143-154$

Gisladottir IV, Oskarsson H (2011) The suitability of the WIV wetland index for Icelandic condtion (Athugun á hentugleika WIV-votlendisvísitölunnar við íslenskar aðstæður). Iceland Agricultural Congress (Fræðaping landbúnaðarins) 2011: 371-376

Gisladottir FO, Metusalemsson S, Oskarsson H (2007) Áhrifasvæði skurða, greining með fjarkönnunaraðferðum (drainage ditch impact areas, a remote sensing study). Iceland Agricultural Congress (Fræðaping landbúnaðarins) 2007:371-376

Gisladottir FO, Gudmundsson J, Askelsdottir S (2010) Mapping and density analyses of drainage ditches in Iceland. Mapping and monitoring of Nordic vegetation and landscapes. Conference Proceeding. Norwegian Forest and Landscape Institute, As, Norway, pp. 43-46

Gisladottir FO, Brink SH, Arnalds O (2014) Nytjaland (The Icelandic Farmland Database). Agricultural University of Iceland Report No. 49. Reykjavik, Iceland.
Gudjonsson G, Gislason E (1998) Vegetation map of Iceland 1:500000. General overview map. Icelandic Institute of Natural History, Reykjavik, Iceland

Gudmundsson GA (1998) The importance of wetlands for birds. In: JS O (ed) Icelandic wetlands, protection and utilization (Íslensk votlendi, verndun og nýting). Háskólaútgáfan (University Publishing). University of Iceland, Reykjavik, pp. 121-129

Gudmundsson T (2008) Carbon sequestraton in soils (Kolefnisbinding í jarðvegi), vol IV. Agricultural Science Conference (Fræðaping landbúnaðarins), Iceland, pp. 290-297

Gudmundsson J, Oskarsson H (2014). Carbon dioxide emission from drained organic soils in West-Iceland. Proceedings of the International conference: Soil carbon sequestration for climate food security and ecosystem services, European Commission Joint Research Centre and The Icelandic Soil Conservation Service, Ispra, Italy, pp. 155-159

Gudmundsson J, Brink SH, Gisladottir FO (2013) Preparation of a LULUCF land-use map for Iceland: development of the grassland layer and subcategories. Grassland Sci Europe 18:105-107

Gunnarsson TG, Gill JA, Appleton GF, Gíslason H, Gardarsson A, Watkinson AR, Sutherland WJ (2006) Large-scale habitat associations of birds in lowland Iceland: implications for conservation. Biol Conserv 128:265-275

Gunnarsson TG, Arnalds O, Appleton G, Mendez V, Gill JA (2015) Ecosystem recharge by volcanic dust drives broad-scale variation in bird abundance. Ecol Evol 5:2386-2396

Helgadottir A, Eythorsdottir E, Johannesson T (2013) Agriculture in Iceland - a grassland based production. Grassland Sci Europe 18:30-43

Hellsing VUL, Ragnarsdottir AS, Jonsson K, Andresson K, Johannsson T, Guðmundsson J, Snorrason A, Thorsson J, Einarsson S (2016) National Inventory Report 2016; submitted under the United Nations framework convention on climate change, emissions of greenhouse gases in Iceland from 1990 to 2014. Environmental Agency of Iceland, Reykjavik, Iceland

IUSS Working Group WRB (2014) World Reference Base for Soil Resources 2014. Intarnational soil classification system for naming soils and creating legends for soil maps. World Soil Resources Reports No. 106. FAO, Rome

Johannesdottir L, Arnalds O, Brink S, Gunnarsson TG (2014) Identifying important bird habitats in a sub-arctic area unergoing rapid land-use change. Bird Study 61:544-552

Johannesson B (1960) The Soils of Iceland. University Research Institute Dept. of Agriculture, Reports Series B - No 13. , University of Iceland, Reykjavik, Iceland

Jones A, Stolbovoy V, Tarnocai C, Broll G, Spaargaren O, Montanarella L (eds) (2010) Soil atlas of the northern circumpolar region. European Comission. Publications Office of the European Union, Luxembourg

Loisel J, Yu Z, Beilman DW, Camill P, Alm J, Amesbury D, Anderson D, Anderson S, Bochicchio C, Barber K, and 51 more authors (2014) A database and synthesis of northern peatland soil properties and Holocene carbon and nitrogen accumulation. The Holocene 24: $1028-1042$

Madeira M, Pinheiro J, Madruga J, Monteiro F (2007) Soils of volcanic systems in Portugal. In: Arnalds O, Bartoli F, Buurman P, Oskarsson H, Stoops G, Garcia-Rodeja E (eds) Soils of volcanic regions in Europe. Springer, Heidelberg, Germany, pp. 69-81

Magnusson B (1998) Vegetation of drained mires in Iceland. In: Olafsson JS (ed) Icelandic Wetlands, Protection and Utilization (Íslensk votlendi, verndun og nýting). Háskólaútgáfan (University Publishing), University of Iceland, Reykjavik, pp 105-120.

Mitsch WJ, Gosselink JG (2007) Wetlands. John Wiley \& Sons, New Jersey

Olafsson JS (ed) (1998) Icelandic wetlands, protection and utilization (Íslensk votlendi, verndun og nýting). Háskólaútgáfan (University Publishing), University of Iceland, Reykjavik 
Oskarsson H (1998) Wetland draining in western Iceland. In: Olafsson JS (ed) Icelandic Wetlands, Protection and Utilization (Íslensk votlendi, verndun og nýting). Háskólaútgáfan (University Publishing), University of Iceland, Reykjavik, pp 121-129.

Oskarsson H, Arnalds O, Gudmundsson J, Gudbergsson G (2004) Organic carbon in Icelandic andosols: geographical variation and impact of erosion. Catena 56:225-238

Pickett SR, Siriwardena GM (2011) The relationship between multi-scale habitat heterogeneity and farmland bird abundance. Ecography 34 : 955-969

Saemundsson T, Arnalds O, Kneisel C, Jonsson HP, Decaulne A (2012) The Orravatnsrustir palsa site in Central Iceland - Palsas in an aeolian sedimentation environment. Geomorphology 167-168:13-20

Shoji S, Ono T (1978) Genesis of andosols at Ktakami, Iwate prefecture, Northeast Japan I Relationships between topography and soil formation. The Quat Res 16:247-254

Sigurdardottir S (2007) Torf til bygginga (turf for buildings). Smarit Byggdasafns Skagfirdinga VII, Sauðárkrókur, Iceland

Skarphedinsson KS, Thorleifsson E (1998) Keldusvín útdauður varpfugl á Íslandi (water rail, extinct bird in Iceland). Kvískerjabók. Sýslusafn Austur Skaftafellssýslu, Höfn í Hornafirði, Iceland, In, pp. 266-296

Snaebjörnsson A, Hjartardottir D, Blöndal E, Petursson JG, Eggertsson O, Halldorsson O (2010) Skýrsla nefndar um landnotkun. Athugun á notkun og varðveislu ræktanlegs lands (Committee report on land use. The use and preservation of arable land), vol 72. Ministry of Fisheries and Agriculture, Reykjavík, Iceland

Soil Survey Staff (1999) Soil taxonomy. A basic system of soil classification for making and interpreting soil surveys. 2nd edn. Agriculture Handbook No 436. USDA/NRCS, Washington
Stefansdottir M (2011) Ecological Restoration by the Road Authorities. In: AL A, Halldorsson G (eds) Restoration in Iceland, Agricultural University of Iceland and the Icelandic Soil Conservation Service, Reykjavik, pp. 56-59. isbn:ISBN:978-9979-881-08-7

Steindorsson S (1964) Gróður á Íslandi (Icelandic vegetation). Almenna bókafélagið, Reykjavík, Iceland

Thordarson T, Höskuldsson A (2008) Postglacial volcanism in Iceland. Jökull - The Icelandic J Earth Sci 58:197-228

Thorhallsdottir TE, Thorsson J, Sigurdardottir S, Svavarsdottir K, Jonsson MH (1998) Disturbance of wetlands in South Iceland. In: JS O (ed) Icelandic Wetlands, Protection and Utilization (Íslensk votlendi, verndun og nýting). Háskólaútgáfan (University Publishing). University of Iceland, Reykjavik, pp. 131-142

Thorleifsson E (1998) Effects of drainage on wetland birds in South Iceland. In: JS O (ed) Icelandic Wetlands, Protection and Utilization (Íslensk votlendi, verndun og nýting). Háskólaútgáfan (University Publishing). University of Iceland, Reykjavik, Iceland, pp. $173-183$

Thorsteinsson G (1975) Horfnir starfshættir og leiftur frá liðnum öldum. Örn og Örlygur, Reykjavík

Wald EC (2012) Land-use development in South Iceland 1900-2010. Faculty of Biology and Environmental Science, University of Iceland, Reykjavík, Iceland, MSc thesis

Wöll C, Hallsdottir BS, Guðmundsson J, Snorrason A, Thorsson J, Jonsson PVK, Andresson K, Einarsson S (2014) Emissions of greenhouse gases in Iceland from 1990 to 2012. National Inventory Report 2014. Submitted under the United Nations Framework Convention on Climate Change and the Kyoto Protocol, Environmental Agency of Iceland, Reykjavik, Iceland 